UDC 621.314

V. Boiko ${ }^{1}$, Dr. Sc. (Tech.), Prof., orcid.org/0000-0003-1018-0642, M. Sotnyk ${ }^{2}$, Dr. Sc. (Tech.), Assoc. Prof., orcid.org/0000-0002-4761-8161,

O. Gusak ${ }^{2}$, Cand. Sc. (Tech.), Assoc. Prof., orcid.org/0000-0003-2530-6770,

S. Khovanskyi ${ }^{2}$, Cand. Sc. (Tech.), Assoc. Prof., orcid.org/0000-0003-2435-7787
DOI: $10.29202 /$ nvngu/2019-2/9

1 - National Technical University of Ukraine "Kyiv Politechnic Institute”, Kyiv, Ukraine, e-mail: vsboiko@bigmir.net 2-Sumy State University, Sumy, Ukraine, e-mail: ni.sotnik@ gmail.com

\title{
POSSIBILITIES TO USE ELECTROANALOGY METHODS FOR ANALYSIS OF WORKING PROCESSES OF WATER SUPPLY NETWORKS
}

Purpose. Development of a new research area related to electroanalogy methods used for modeling working processes in electromechanical systems of water supply networks.

Methodology. The methodology of the research is based on applying power electronics methods used while analyzing electromagnetic processes as well as methods of circuit modeling with the use of schemes of electric models.

Findings. It is shown that the circuit design of electric models of electromechanical systems with piston pumps differs from circuits of such systems with centrifugal pumps. The circuits of the former ones are simpler and can be realized in the form of specific physical objects. Not every circuit with centrifugal pumps is physically realizable. However, it does not present an obstacle for their use while analyzing electromagnetic processes in electric models, as evidenced by the agreement of the results of analytical studies with the results of circuit modeling.

Originality. The authors' research proved possibility of developing electric models of the electromechanical systems with piston and centrifugal pumps constructed on the common basis which is presented by electric energy converter - a rectifier.

Practical value. Development of electric models of electromechanical systems of water supply networks allows modeling and investigating working processes in water supply networks.

Keywords: pump, energy, energy efficiency, circuit model, electromagnetic process

Introduction. The main equations of the motion of a liquid, considering frictional force taken relative to the unit mass of fluid, involve the Navier-Stokes equation. These differential equations are used to analyze any motion practically with no limits on the geometry of channels and hydrodynamic flow patterns and describe the flow of fluids in any space [1]. The only limitation is that they can be used only to the flow of Newtonian fluids. To write the regularities of the flow of non-Newtonian fluids, these equations were subsequently supplemented and somewhat modified when the characteristics of non-Newtonian fluids became known. In general, there is no uniquely analytic solution of the Navier-Stokes equation. The analytic solution of the equations is known only for a very limited set of problems, and then, only for laminar steady-state flows. In all other cases, solving equations for practical tasks is possible only with the use of process simulation methods.

Recently methods of mathematical modeling have become popular. Such models are usually developed when the picture of the occurrence of physical phenomena and processes is not well understood, and when it is not possible to describe a phenomenon by the corresponding equation that reflects the physical or other side of it. In the presence of given value intervals of variables, the mathematical models developed are usually calculated using software [2-4], which uses the STAR-CCM

(C) Boiko V., Sotnyk M., Gusak O., Khovanskyi S., 2019
+ hydrodynamic modeling package or the STAR-CD program complex. Methods based on MATLAB system [5] and numerical experiment [6], in ANSYS package, or other programs, such as [7], are also used.

Moreover, physical modeling is used. Physical modeling means, first of all, material modeling, that is, the development of physical models of real objects and the subjection of these models to special experiments. Then the experimental data are processed, generalized and, as a rule, the result of experiments involves equations, which are called empirical. With the development of computer technology, the proportion of physical modeling in the overall model of hydrodynamic processes is reduced, since physical modeling is more costly in terms of the use of financial or time resources.

Also purely electric methods of simulation are being developed [8]. In the opinion of the authors, the latter are the most promising for studying working processes of water supply networks, since their modeling by electrical methods allows us to analyze not only steady-state processes, but also transient ones.

Analysis of the recent research and publications. A significant contribution to the development of electroanalogy methods was made by academician Pavlovsky M.I., who in 1918-1922 justified the principles of electrohydrodynamic analogy, based on the mathematical analogy between equations that describe the motion of fluid in some hydraulic systems and the flow of electric current in a conducting medium. He used this 
method in practice while studying a laminar flow of groundwater during its filtration through the earthen dam. The potential of electroanalogy methods for modeling processes in pump units was studied in one of the sections of the PhD thesis by Grigorovsky Ye. P., for which he used a physical model with incandescent lamps.

Another approach to the modeling of hydraulic processes was developed by H. O. Ryazanov. It lies in the use of electric curl fields. In this case, flat and axisymmetric circulation flows are simulated on physical models. H.O. Ryazanov uses a steady electrical field with voltage $E$ as a mathematical analogue of velocity field $v$. This physical modeling of hydraulic processes is costly and long-lasting, since it requires the construction of physical models. Its results are largely demonstrative. In addition, such models do not provide the possibility to model pump units.

Unsolved aspects of the problem. The approaches of classical applied hydromechanics are based on the use of simplified methods of fluid flow modeling in hydraulic systems [9] and the application of integrated fluid flow characteristics and empirical equations to describe energy losses due friction. In addition, the nonlinearity of the hydraulic system and a number of inherent technical features are not taken into consideration.

The previously developed methods, built on the use of electrical analogy, did not find a wide practical application. In our opinion, there are two main reasons: the lack of powerful computers at that time and the inability to create an adequate electric model of a pump unit, and in the broader aspect - the lack of an electric model of the electromechanical system.

The method of study. The authors developed a purely electroanalogy method for modeling of the electromechanical system elements, in which they operate with the basic electrical characteristics (resistance, current, voltage, power, and others). It follows from the performed studies that, despite the wide range of electromechanical water supply systems, whose working processes are modeled by electrothechnical methods and electric models, all the latter ones have a common basis, which is a converter of electric energy. In some cases, the circuit construction of electric models is rather peculiar and unusual, compared to the well-known circuits of power electronic devices. Some electric models can be implemented as an electrical device, while others cannot. The latter exist only in the form of a model structure or a mathematical model implemented by means of computing in a package of circuit modeling. Despite this (the lack of the possibility of physical implementation of the model), the results of such modeling are suitable for practical use while determining the set of requirements to electromechanical systems of water supply networks, the harmonization of which allows obtaining the highest possible energy efficiency of their operation. The last thesis does not contradict the approaches of theoretical electrical engineering. For example, with the application of equivalent of four-pole, some of them may not be suitable for physical implementation, but this is not an obstacle to their application in the analysis of electromagnetic processes in electric circuits with such equivalent circuits.

Research objectives. The development of basic principles of electroanalogy method for working processes of electromechanical systems of water supply networks and scientific principles of their circuit construction.

Research results. Electroanalogy of working processes of electromechanical systems of water supply networks is a relatively new research area aimed at increasing the energy efficiency of their operation. The electroanalogy method proposed by the authors to model the working processes of electromechanical systems with centrifugal pumps [8] generalizes the study of the working process of the water supply network, regardless of the characteristics of the electromechanical system. The EMS electrical models, which are used for this, consider the following design and performance characteristics of the system components:

- energy component in all its manifestations;

- conditions for converting one kind of energy to another;

- design features of a pump impeller;

- features of the pump unit discharge;

- the presence of shut-off and control valves.

An electromechanical system is the main energy element of any water supply network. It consists of: a power supply system, an electric drive motor, a pump, a system for supplying fluid from storage tanks and a system for discharge of fluid flow.

In the generalized circuit of any hydraulic network, primary electric power consumers are electric drive motors which are powered from a power supply network. Together with the means of control, they create an incoming subsystem of the general water supply network. There is no doubt that in implementing a hydraulic water supply network, in order to increase its energy efficiency, it is desirable to use electric drive motors with the highest efficiency possible. However, the high efficiency of a motor does not guarantee high energy efficiency of the system as a whole $[5,9]$.

The decision to use one or another electric drive motor shall be made with consideration that the given subsystem also consists of separate components. The requirement for strict control over the operation of components of the subsystem is based on the fact that the main reason for the excessive energy loss is the suboptimal distribution of it within the system or subsystem.

Another subsystem consists of the reservoirs-liquid storage (buffer tanks, storage tanks, forebays, and so on), pipelines (conduits), shut-off valves on the suction side. It is also a subsystem which transfers energy into the main elements of the hydraulic system, the pumps, but it transfers not the mechanical energy, but the potential energy of the fluid being pumped. This is a significant energy component that can seriously affect the overall energy efficiency of the system.

From the basic equation of hydrostatics, it is known that the pressure $p$ at any point of the fluid which is in a state of zero motion can be represented as the pressure $p_{0}$ acting on its free surface and the pressure $\gamma h$, which de- 
pends on the depth $h$ of the location of this point and the specific gravity of the liquid $\gamma$

$$
p=p_{0}+\gamma h \text {. }
$$

If we consider that in most cases the main storage tanks have a free surface being in contact with atmospheric air, then the external pressure $p_{0}$ is atmospheric, and the main technological processes of water consumption in consumers are also carried out under atmospheric pressure, then it is obvious that the component $\gamma h$, which is also called equilibrium pressure, has a significant impact on the energy component of the process of fluid transportation by the hydraulic system. In this case, by $h$ we mean the surface level of the fluid relative to the rotation axis of the rotor (impeller) of the pump, or the difference between levels of the fluid of the storage tank and the consumer. In this case, the potential energy of the fluid is determined by the difference in the geodetic levels of the relative arrangement of the rotation axis of the pump impeller and fluid surface. In the general case, the volume of the fluid in such tanks is not constant; therefore, the geometric sizes of the tanks influence the level of the liquid. The larger tanks are, the less ratio of the liquid level in the tank to its area is, the more slowly the fluid level in it decreases, and the less the change of the potential energy of the liquid is. This factor should always be considered when designing systems and calculating the cost of their life cycle. The features of tanks' geometry can significantly affect the pressure of end consumers of the network and it is necessary to know the principles of level change versus time, as a function of the network cost and schedule of their filling.

In light of the foregoing, the electromechanical system is a kind of multi-stage converter as to their function, in which the electric energy supplied from the power network by electric drive motor and the potential energy of the liquid of the storage tanks are converted into the energy of the fluid flow in the discharge nozzle.

Fig. 1 shows behavior of the instantaneous change of the head at the outlet of Д 2000-100 pump with a $620 \mathrm{~mm}$ six-blade impeller at nominal flow rate $\left(Q_{\text {nom }}\right)$ and at a flow rate of $60 \%$ of the nominal $\left(0.6 Q_{n o m}\right)$ per one full rotation of the pump impeller obtained at simulation the working process of the hydraulic network in the ANSYS CFX 12.0. As can be seen, the given curves have six pulsations over a period the depth of which de-

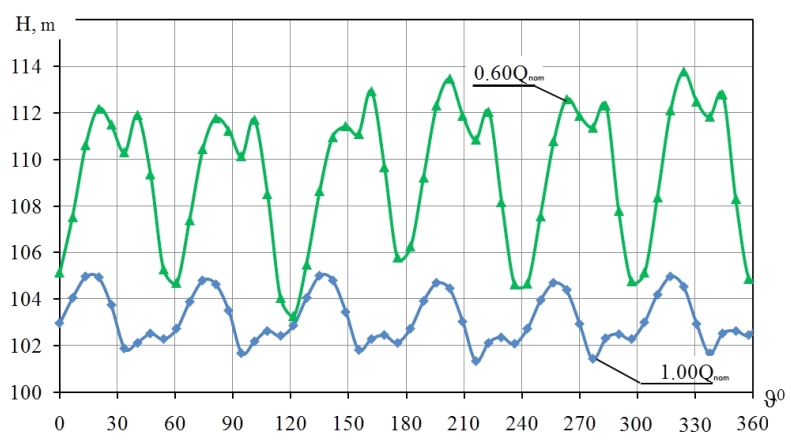

Fig. 1. Instantaneous change of the head at the outlet of Д 2000-100 puтр pends on the load value of the electromechanical system.

Among the circuits, by which converters of electrical energy intended for direct supply of technological consumers are implemented, there is a circuit called "sixphase single-stroke valve circuit", given in [7] and shown in Fig. 2

The circuit consists of a six-phase transformer and six valves (diodes). The vectors of the secondary phase voltages are shifted to each other by phase by $\pi / 3$, so the number of pulsations of the rectified voltage $m=6$.

In this circuit, each valve conducts current within one sixth of the period. The shape of the rectified voltage curve and the pulsation depth depend on the parameters of the circuit elements and the value of the load current. Typical power of the transformer $P_{T}$ and the power of the rectified current circle $P_{d}$ are related as $P_{T}=$ $=1.55 P_{d}$. Due to the increased design power of the transformer and a small extension of the current through the valves, the practical application of such circuit for implementation as a converter of electrical energy is limited.

This is not an obstacle to use this circuit as part of an electric model of electromechanical system of water supply networks. The latter does not contain elements that would be modeled by a transformer of electric energy. In the electric model of the water supply network only the valve part of the converter and its load circle are used. The energy component of the electromechanical system, which is provided by the energy supplied by the electric drive motor and the energy of the inlet fluid flow, is presented in a circuit of the electric model as a set of separate sources of electromotive force (EMF). Their number in the electric model of EMS is equal to the number of blades of the pump impeller, which corresponds to the physics of the energy-transfer process of the fluid flow, which goes out the pump through the blade system of the impeller.

The amplitude of EMF of such sources corresponds to the required value of the head at the pump outlet, and the angular velocity $\omega$ corresponds to the rotational speed $n$ of the pump impeller

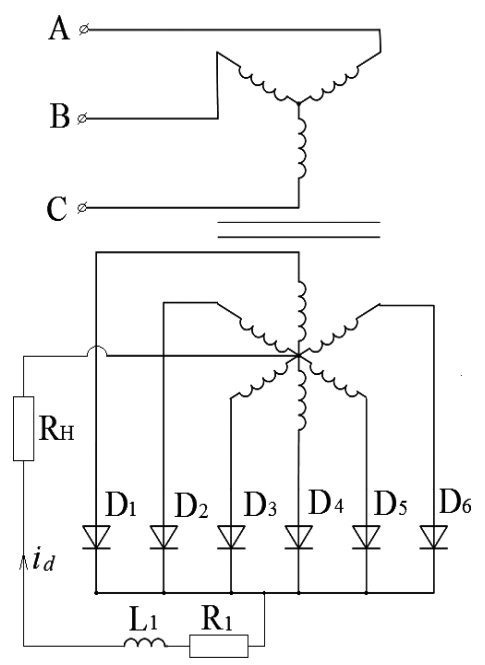

Fig. 2. Six-phase single-stroke valve circuit 


$$
\omega=\frac{\pi \cdot n}{30} .
$$

Assume that EMS includes a single volute centrifugal pump with an impeller which has $m$ blades. Each blade of the impeller passes the cutwater of the volute one time per one revolution (we assume, for a period) and pushes fluid into the outer network. Due to this process, the rotating motion of the fluid in the impeller is converted into a single-directional motion in the volute.

Exactly the same physical process occurs in the rectifier, which is the basis of the electric model of the electromechanical system of the water supply network.

The circuit of the electric model of EMS, which includes a single volute centrifugal pump with an impeller which has $m$ blades, is shown in Fig. 3

It consists of $m$ parallel lines, each of which contains the following sequentially connected units: a source of sinusoidal EMF

$$
e_{j}=E_{m} \sin \left[\omega t+\pi\left(0.5+\frac{1-2 j}{m}\right)\right],
$$

active resistance $R_{r}$; inductance $L_{r}$; diode D.

The energy losses in the volute are modeled by the circuit elements $R 1, L 1$, and the resistance of the $R_{H}$ generalizes the presence of the water system and consumer.

The sinusoidal source of EMF of each line of the circuit has the same value of the amplitude value and represents the rotating motion of the fluid in the pump impeller, its angular velocity is calculated by the equation (1), and the angle of shift by phase is calculated as follows

$$
\psi_{j}=\pi\left(0.5+\frac{1-2 j}{m}\right) .
$$

An analogue of the working process in an electromechanical system with a centrifugal pump is the electromagnetic process in its electric model, which, at bottom, is a one-stroke six-pulse rectifier. The results of the study of electromagnetic processes in such electric model during the modeling of working processes of the

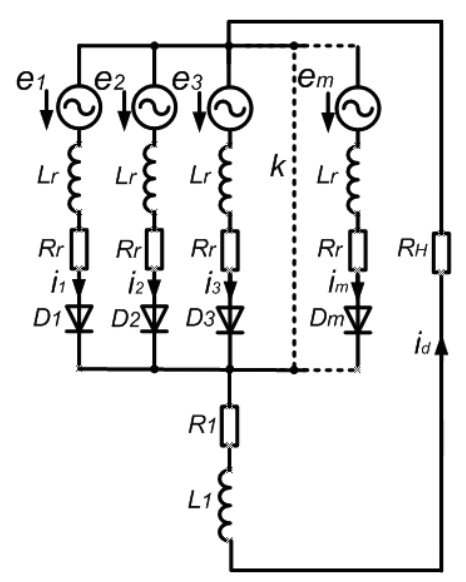

Fig. 3. Electric model of EMS, which includes a pump with an impeller which has $m$ blades electromechanical system of the water supply system are given in [10], where the issue of modeling adequacy was considered on the basis of Д 2000-100 pump unit with a six-blade impeller. As for the rectified voltage of the electric model, on the first interval, the length of which is the switching interval and measured by switching angle $\gamma(0 \leq \vartheta \leq \gamma)$, its instantaneous value in the general form will be written as follows

$u_{d(1)}=\sqrt{3} E_{m} \sin (\vartheta+\pi / 2) / 2-R_{r} E_{m}(1-\cos \vartheta) / 2 x_{\gamma}$,

where $x_{\gamma}$ is induced resistance of commutation circuit.

The second interval has the length $\gamma \leq \vartheta \leq \pi / 3$ and the following relation of change in the instantaneous value of the rectified voltage in the general form

$$
\begin{gathered}
u_{d(2)}=E_{m} \sin (\vartheta+\pi / 3)-x_{\gamma} E_{m} \cos (\vartheta+\pi / 3-\varphi) / Z+ \\
+R_{r} A e^{-\frac{R_{e}}{x_{\gamma}(\vartheta-\gamma)}}-\left(R_{r}+R_{1}\right) E_{m} \sin (\vartheta+\pi / 3-\varphi) / Z .
\end{gathered}
$$

The total length of the two intervals according to the equations $(4,5)$ is one sixth of the period, so the instantaneous value curve of the rectified voltage of EMS electric model with Д 2000-100 centrifugal pump has six pulsations for a period corresponding to the work of the six-pulse rectifier. The depth of pulsation depends on the parameters of the elements of the electric model and the value of its load.

The study of working processes of water supply networks during the application of their electric models is carried out according to the methods developed for the study of electromagnetic processes in devices of energy electronics.

Note that single-volute centrifugal pumps may have impellers not only with six blades, but also with three, five, seven or eight blades. Accordingly, the circuit of the electric model of the electromechanical system (Fig. 3) can have three, five, six, seven or eight parallel lines. Circuits with three and six lines can be physically implemented and are actually used as power supplies of the direct current of technological consumers. Circuits with a different number of parallel lines are not physically implemented because of the lack of simple means for obtaining the required phase shift EMF of individual phases, but this is not necessary. They are used for circuit modeling of working processes of electromechanical systems using computers with standard software packages.

The results of the studies described in [10], proved the adequacy of electroanalogy method used for modeling of working processes of EMS which has a singlevolute centrifugal pump and it is found that "... The biggest discrepancy between the values of output characteristics of a centrifugal pump and its electric models takes place in overload modes... the overload of $10 \%$ results in $5 \%$, the overload of $20 \%$ (pump capacity of $2,400 \mathrm{~m}^{3} / \mathrm{h}$ ) results almost in $10 \%$. The simulation uncertainty is about $3 \%$ at the rated load, which are rather acceptable values".

If EMS has a double volute centrifugal pump, the circuit of the electric model becomes more complicated 
due to more complicated implementation of such systems and more diverse working processes of them. Fig. 4 shows a circuit of electric model of EMS, which includes a double volute centrifugal pump with impeller which has $m$ blades.

As in the case of modeling of EMS of water supply network with single-volute centrifugal pumps, the circuit elements shown in Fig. 4 are not a set of mathematical models of individual components of the electromechanical system.

The electromotive forces $e_{1} \ldots e_{14}$ model the physical process of energy transfer from the pump drive motor into the electromechanical system with simultaneous energy conversion by form and frequency. These EMFs have the equal length and are sinusoidal reflecting rotating fluid flow in the centrifugal pump impeller. The voltage frequency of this EMF is calculated by equation (1).

For the left part of the electric model of EMS (first block) which has $m$ parallel lines, the system of their EMF is written in the form of harmonic functions (2).

The initial phase of EMF of the first block is calculated by equation (3). The initial phase of the EMF of the second block, the circuit of which also consists of $m$ parallel lines, has a phase shift by angle $\pi$ (1800) relative to EMF of the corresponding phases of the first block.

Please note that electromechanical systems with double-volute pumps are fitted with impellers with seven or eight blades.

The rotating motion of the fluid flowing through hydraulic passage of a centrifugal pump transfers into onedirectional flow in volute, so the output of electric model of electromechanical system is a one-stroke rectifier. In electric models of electromechanical systems with single or double volute pumps with impellers which have an even number of blades, the energy conversion process is $m-$ phase. In electric models of EMS that include double volute pumps with impellers which have an odd number of blades, the pulse number of conversion is twice and equals $2 m$. The rectified current in load resistance of electric model has $2 m$ pulsation per period $T=2 \pi$, corresponding to doubling of the frequency head curve at pump outlet under the above mentioned conditions.

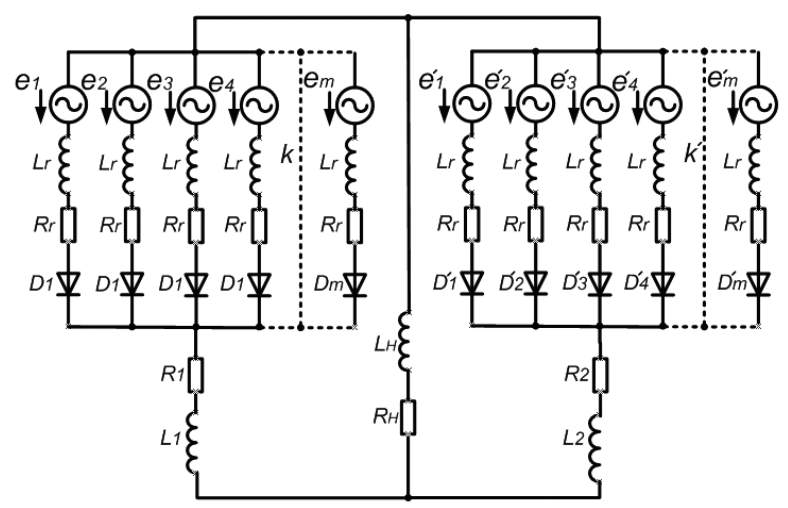

Fig. 4. Electric model of EMS, which includes a double volute centrifugal pump with impeller which has $m$ blades
The processes occurring in the diffuser - an outlet part of the pump, are also characterized by active energy losses and inertial processes. However, in contrast to the electric models with single volute pumps, in EMS models with double volute pumps each part of the circuit has its own outlet line, whose electrical parameters (active resistance and inductance) are different.

All circuit of electrical models of EMS with double volute pumps are intended to use them as circuit models while modeling working processes of electromechanical systems separately or as a part of water supply networks by computer. The purpose of these studies is not to design new pump units being a part of EMS, but to determine the conditions of the energy efficiency operation of existing pump units being a part of EMS and to develop requirements for improvements of the last one to agree them with the characteristic curves of the water supply network.

The high level of similarity of the obtained results shows the possibility to develop a generalized approach for modeling working processes of water supply networks with centrifugal pumps using the electroanalogy method. The main factors of the electroanalogy method are summarized in the Table below.

The electroanalogy method proposed by the authors to model working processes of electromechanical systems with centrifugal pumps covers EMSs, which also include piston pumps.

The study of processes in piston pumps carried out by Europump and the Hydraulic Institute (HI) of the United States and published in technical publications shows that the relation of flow rate versus time of these pumps $Q(t)$ quite acceptably coincides with the relation the rectified voltage of some converting devices. The working process of a single-piston pump (or simplex pump) can be modeled by the operation of a singlephase diode semiconductor rectifier, which conducts a current in a positive half-period of the power supply regarding the diode, while in a negative one it does not. A similar process takes place in the pump, when during the first half of the working cycle the cylinder is filled, there is no flow at the discharge at this time. The second half of the working cycle is effective, when the piston displaces fluid from the cylinder. As noted in Europump's published paper, "... performance is a set of sinusoidal maxima".

If the piston pump has two cylinders (duplex pump), then its working process differs from the simplex pump process by double frequency. Such a working flow corresponds to an electric model based on the well-known circuit of a single-phase rectifier with an average point.

In the three-piston pump (or triplex pump), due to the additional third set of parts, a significant difference is achieved, as there are two plungers at two-thirds of the piston stroke, that simultaneously discharge, and one plunger at one-third, that is close to the maximum flow rate. The common capacity of the three components provides a fluid flow at outlet with a slight depth of pulsation. The value of capacity varies from 90 to $104 \%$ of the average value, that is, by a total of $14 \%$. 
Table

The main factors of the electroanalogy method

\begin{tabular}{|c|c|}
\hline $\begin{array}{l}\text { Pump unit with } \\
\text { centrifugal pump }\end{array}$ & $\begin{array}{l}\text { Electric model of } \\
\text { a pump unit }\end{array}$ \\
\hline $\begin{array}{l}\text { Flow rate of pump unit } Q \\
{\left[\mathrm{~m}^{3} / \mathrm{s}\right]}\end{array}$ & Electric current $i[\mathrm{~A}]$ \\
\hline Head of pump unit $H[\mathrm{~m}]$ & Electrical voltage $u[\mathrm{~V}]$ \\
\hline $\begin{array}{l}\text { Availability of electric motor } \\
\text { and rotational motion in blade } \\
\text { channels of pump impeller }\end{array}$ & $\begin{array}{l}\text { Availability of sources of } \\
\text { sinusoidal EMF in the lines } \\
\text { of the electric model }\end{array}$ \\
\hline $\begin{array}{l}\text { The number of blades of } \\
\text { pump impeller (m) }\end{array}$ & $\begin{array}{l}\text { The number of phases of the } \\
\text { block of the electric model } \\
\text { (m) }\end{array}$ \\
\hline $\begin{array}{l}\text { Shift of impeller blades on } \\
\text { perimeter of its outer } \\
\text { diameter } \psi_{j}=2 \pi / \mathrm{m}\end{array}$ & $\begin{array}{l}\text { Phase shift of the sinusoidal } \\
\text { EMF of the lines of the } \\
\text { electric model } \\
\psi_{j}=\pi\left(0.5+\frac{1-2 j}{m}\right)\end{array}$ \\
\hline $\begin{array}{l}\text { Shut-off head } H_{0}[\mathrm{~m}] \text { and } \\
\text { the number of impeller } \\
\text { rotation per second } n[1 / \mathrm{s}]\end{array}$ & $\begin{array}{l}\text { Amplitude of the sinusoidal } \\
\text { sources of EMF of the lines } \\
\text { of the electrical model } \\
E_{m}=k H_{0}[\mathrm{~V}] \text { and their } \\
\text { frequency } f[\mathrm{~Hz}]\end{array}$ \\
\hline $\begin{array}{l}\text { Hydraulic resistance caused } \\
\text { by viscous friction between } \\
\text { layers of fluid and other } \\
\text { active energy losses in a } \\
\text { centrifugal pump }\left[\mathrm{s} / \mathrm{m}^{2}\right]\end{array}$ & $\begin{array}{l}\text { Active hydraulic resistance } \\
R_{H}[\mathrm{Ohm}] \text { and other active } \\
\text { supports } R[\mathrm{Ohm}]\end{array}$ \\
\hline $\begin{array}{l}\text { Inertance of the hydraulic } \\
\text { flow in a centrifugal pump } \\
{\left[\mathrm{s}^{2} / \mathrm{m}^{2}\right]}\end{array}$ & $\begin{array}{l}\text { Inductance of the electric } \\
\text { model } L_{r}[\mathrm{Hn}]\end{array}$ \\
\hline $\begin{array}{l}\text { Pump volute that forms } \\
\text { unidirectional motion }\end{array}$ & $\begin{array}{l}\text { One-stroke uncontrolled } \\
\text { rectifier }\end{array}$ \\
\hline Single volute & $m-$ pulse rectifier \\
\hline $\begin{array}{l}\text { Double-volute and impeller } \\
\text { with odd number of blades }\end{array}$ & $2 m-$ pulse rectifier \\
\hline
\end{tabular}

In industrial electronics, a three-phase bridge rectifier circuit is known (Larionov's circuit), which can be the basis of the electric model of an electromechanical system with a three-piston pump. This is confirmed both by performed studies and by such simple calculation.

The average value of the rectified voltage of the three-phase bridge rectifier is calculated in the interval of repetition, which is $\pi / 3$

$U_{d}=\frac{1}{\pi / 3} \int_{0}^{\frac{\pi}{3}} e d t=\frac{3}{\pi} \int_{0}^{\frac{\pi}{3}} E_{m} \sin \left(\omega t+\frac{\pi}{3}\right) d(\omega t)=\frac{3}{\pi} E_{m}$.

The coefficient connecting the amplitude value of the three-phase bridge rectifier EMF sources and the average value of its rectified voltage is $3 / \pi$ or 0.955 . If the average value of the rectified voltage is taken at 100 $\%$, then the amplitude will be $104 \%$ of it, as indicated in the analysis of working process in a three-piston pump.
The above is a powerful argument for the idea to model working processes in electromechanical systems of water supply networks with piston pumps, as well as in systems with centrifugal pumps, by electric models, the main component of which is the electrical energy converter-rectifier.

\section{Conclusions.}

1. The given study results are aimed at development of a new scientific area related to electric methods for modeling working processes in electromechanical systems of water supply networks or water supply networks with electromechanical systems, which include piston and centrifugal pumps.

2. All electric models of electromechanical systems have a common circuit basis, it is an electric energy converter, and they also have common ground of research; these are analytical and circuit methods of power electronics.

3. The electric models of EMS of water supply networks allow modeling and studying working processes in water supply networks of any configuration as well as obtaining the data needed to achieve maximum energy efficiency of their operation.

\section{References.}

1. Valyukov, S. G. and Obolonskaya, E. M., 2013. Development of Mathematical Apparatus for Construction of Parameterized 3D Model of double volute. Pumps. Turbines. Systems, 4, pp. 66-79.

2. Lomakin, V. O., Petrov, A. I. and Kuleshov, M.S., 2014. Study of Two-Phase Flow in Mixed-Flow Centrifugal Pump Using Computational Fluid Dynamics. Science and Education: Electronic Scientific and Technical Publication, 9, pp. 45-64.

3. Petrov, A. I. and Isaev, N. Yu., 2017. Study of Vane Pump Operated Within Negative Range of Capacities Using Computational Fluid Dynamics. Scientific Review, 13, pp. 75-80.

4. Kuleshov, M.S., Getmantseva, E.V. and Chaburko, P. S., 2014. Study of Flows in Channel-Eype Diffuser of ЦНС Centrifugal Pump Using Hydrodynamic Analysis Methods. Youth Scientific and Technical Reporter, 3, pp. 56-63.

5. Rushkin, E. I. and Semenov, A. S., 2013. Analysis of Energy Efficiency of Electric Motor System of Centrifugal Pump Using Simulation in the MATLAB System. Modern High Technologies, 8-2, pp. 341-342.

6. Shevchenko, N. G. and Shudrik, A. L., 2015. Numerical Simulation of Viscous Fluid Flow in Stage of Submersible Centrifugal Pump. Reporter of NTU KhPI, 3(1112), pp. 59-67.

7. Zotov, B. N., 2016. Program for Calculation of Expected Energy Characteristics of Centrifugal Pumps. Moscow: ECOPUMP-RUS.

8. Boiko, V.S., Sotnik, N.I. and Khovanskyi, S.A., 2015. Electrical Modeling of Workflows in Electrical Systems of Water Supply Networks. Journal of Engineering Sciences, 2(2), pp. E1-E12.

9. Grigoriev, S. V., Savin, L.A. and Shahbanov, R. M., 2015. Substantiation of Possibility to Improve Energy Characteristics of Centrifugal Pumps. News of TSU. Technical Science, 7.42, pp. 122-127. 
10. Boiko, V.S. and Sotnik, M. I., 2013. Adequacy of Electrical Simulation Workflows in Centrifugal Pump. Technical Electrodynamic, pp. 90-96.

\section{Можливості застосування електричних методів моделювання до аналізу робочих процесів мереж водопостачання}

$$
\begin{gathered}
\text { В. С. Бойко }{ }^{1} \text {, М. І. Сотник }{ }^{2} \text {, О. Г. Гусак }{ }^{2} \text {, } \\
\text { С. О. Хованський }
\end{gathered}
$$

1 - Національний технічний університет України „Київський політехнічний інститут“, м. Київ, Україна, е-mail: vsboiko@bigmir.net

2 - Сумський державний університет, м. Суми, Україна, e-mail: ni.sotnik@gmail.com

Мета. Розвиток нового наукового напряму електричних методів моделювання робочих процесів в електромеханічних системах мереж водопостачання.

Методика. Методика дослідження побудована на застосуванні методів силової електроніки, що використовуються при аналізі електромагнітних процесів, і методів схемотехнічного моделювання $з$ використанням схем електричних моделей.

Результати. Показано, що схемотехнічна побудова електричних моделей електромеханічних систем із поршневими насосами відрізняється від схемотехнічної побудови таких систем з відцентровими насосами. Схеми перших є більш простими й можуть бути реалізованими у вигляді конкретних фізичних об'єктів. Схеми систем із відцентровими насосами не всі придатні до фізичної реалізації. Однак це не $є$ перешкодою для їх застосування при аналізі електромагнітних процесів в електричних моделях, про що свідчить збіг результатів аналітичних досліджень і схемотехнічного моделювання.

Наукова новизна. Дослідженнями авторів доведена можливість створення електричних моделей електромеханічних систем із поршневими та відцентровими насосами, що побудовані на спільній основі, якою є перетворювач електричної енергії випрямляч.

Практична значимість. Створення електричних моделей електромеханічних систем мереж водопостачання дозволяє моделювати й досліджувати робочі процеси в мережах водопостачання.

Ключові слова: насос, енергія, енергоефективність, схемотехнічна модель, електромагнітний проиес

\section{Возможности применения электрических методов моделирования к анализу рабочих процессов сетей водоснабжения}

\author{
В. С. Бойко , Н. И. Сотник ${ }^{2}$ О. Г. Гусак ${ }^{2}$, \\ С.А.Хованский
}

1 - Национальный технический университет Украины „Киевский политехнический институт“, г. Киев, Украина, e-mail: vsboiko@bigmir.net

2 - Сумский государственный университет, г. Сумы, Украина, e-mail: ni.sotnik@gmail.com

Цель. Развитие нового научного направления электрических методов моделирования рабочих процессов в электромеханических системах сетей водоснабжения.

Методика. Методика исследования построена на применении методов силовой электроники, используемых при анализе электромагнитных процессов, и методов схемотехнического моделирования с использованием схем электрических моделей.

Результаты. Показано, что схемотехническое решение электрических моделей электромеханических систем с поршневыми насосами отличается от схемотехнического построения таких систем с центробежными насосами. Схемы первых являются более простыми и их можно реализовать в виде конкретных физических объектов. Схемы систем с центробежными насосами не все физически реализуемы. Однако это не является препятствием для их использования при анализе электромагнитных процессов в электрических моделях, о чем свидетельствует совпадение результатов аналитических исследований с результатами схемотехнического моделирования.

Научная новизна. Исследованиями авторов доказана возможность создания электрических моделей электромеханических систем с поршневыми и центробежными насосами, построенных на общей основе, которой является преобразователь электрической энергии - выпрямитель.

Практическая значимость. Создание электрических моделей электромеханических систем сетей водоснабжения позволяет моделировать и исследовать рабочие процессы в сетях водоснабжения.

Ключевые слова: насос, энергия, энергоэффективность, схемотехническая модель, электромагнитный проиесс

Рекомендовано до публікації докт. техн. наук о.О.Ляпощенком. Дата надходження рукопису 19.12.17. 